\title{
PENGARUH PENDIDIKAN, PEKERJAAN DAN PENDAPATAN ORANG TUA TERHADAP PRESTASI BELAJAR EKONOMI PADA SISWA SMA
}

\author{
Herman Hadiyanto, SMA Negeri 15 Surabaya
}

\begin{abstract}
ABSTRAK
Tujuan dari penelitian ini untuk mengetahui pengaruh pendidikan, pekerjaan dan pendapatan orang tua terhadap prestasi belajar ekonomi secara parsial dan simultan. Penelitian ini menggunakan pendekatan kuantitatif, dengan menggunakan uji asumsi klasik, regresi linier berganda dengan uji $\mathrm{F}$ dan uji $\mathrm{T}$. Hasil penelitian menunjukkan pengaruh pendidikan orang tua tidak berpengaruh signifikan terhadap prestasi belajar ekonomi, sedangkan pekerjaan dan pendapatan orang tua berpengaruh signifikan terhadap prestasi belajar ekonomi. Variabel pendidikan, pekerjaan dan pendapatan orang tua secara simultan berpengaruh signifikan terhadap prestasi belajar ekonomi.
\end{abstract}

Kata Kunci: pendidikan, pekerjaan, pendapatan orang tua, prestasi belajar ekonomi

\section{ABSTRACT}

This study aimed to determine the influence of parental education, occupation, and income on economic achievement; determine the influence of parental education, occupation and income simultan against economic achievement. This study used a quantitative approach, was analyzed by using the classical assumption test, multiple regression analysis with $F$ test (simultaneous influence test) and $t$ test (parsial influence test). The findings showed that parental education did not affect significantly on the achievement of economic, parental occupation and parental income affected significantly on the achievement of economic. As well as the variables of education, occupation and income of parents affected significantly oneconomic achievement.

Keyword: parent's education, occupation, income, achievement

\section{PENDAHULUAN}

Bertitik tolak pada undang-undang sistem pendidikan nasional diharapkan memungkinkan setiap peserta didik mempertahankan hidupnya, mengembangkan dirinya, dan secara bersama-sama membangun masyarakatnya. Setiap peserta didik harus mampu menghayati nilai-nilai secara kreatif serta dapat meningkatkan kemampuan memperoleh dan menciptakan prestasi melalui bermacam-macam kemungkinan ditengah-tengah tuntutan masyarakat semakin kompleks dan persaingan yang semakin ketat. Pendidikan merupakan salah satu faktor utama bagi pengembangan sumber daya manusia karena pendidikan diyakini mampu meningkatkan sumber daya manusia sehingga dapat menciptakan manusia produktif yang mampu memajukan bangsanya.

Pendidikan dapat mengandung pengertian mendidik, membimbing, mengajar dan melatih yang tertuang dalam proses pendidikan di sekolah. Sekolah sebagai lembaga pendidikan formal merupakan sarana dalam rangkapencapaian tujuan pendidikan melalui proses belajar mengajar. Dengan belajar peserta didik dapat 
menunjukkan adanya perubahan yangsifatnya positif sehingga pada tahap akhir akan didapat keterampilan, kecakapan danpengetahuan baru. Hasil dari proses belajar tersebut tercermin dalam prestasi belajarnya.

Kenyataan bahwa hasil ulangan tengah semester (UTS) ganjil mata pelajaran ekonomi tahun pelajaran 2012-2013 pada siswa kelas XI IPS dan XII IPS, kurang mencapai ketuntasan belajar yang ditentukan sekolah. Dari jumlah tersebut yang mendapat nilai sama dan di atas KKM hanya 48\% siswa sedangkan yang mendapat nilai di bawah KKM sebanyak 52\%. Artinya jumlah siswa yang tuntas lebih kecil daripada jumlah siswa yang belum tuntas.

Prestasi merupakan hasil yang dicapai seseorang ketika mengerjakan tugas atau kegiatan tertentu. Sementara prestasi belajar adalah penguasaanpengetahuan atau keterampilan yang dikembangkan oleh mata pelajaran, lazimnya ditunjukkan dengan nilai tes atau angka nilai yang diberikan oleh guru (Tu'us, 2004). Adapun menurut Azwar (2010) prestasi belajar merujuk pada apa yang mampu dilakukan olah seseorang dan seberapa baik ia melakukannya dalam menguasai bahan-bahan dan materi yang telah diajarkan. Sedangkan Gintings (2010) mengemukakan prestasi belajar siswa adalah hasil dari berbagai upaya dan daya yang tercermin dari partisipasi belajar yang dilakukan siswa dalam mempelajari materi pelajaran yang diajarkan oleh guru. Poerwanto (2007) mengemukakan pengertian prestasi belajar yaitu hasil yang dicapai oleh seseorang dalam usaha belajar sebagaimana yang dinyatakan dalam raport.

Keberhasilan prestasi belajar yang diperoleh siswa dapat dipengaruhi oleh beberapa faktor. Menurut Dalyono (2009) faktor-faktor yang mempengaruhi prestasi belajar adalah tinggi rendahnya pendidikan orang tua dan besar kecilnya penghasilan orang tua. Sedangkan menurut Suryabrata (2004), faktor-faktor dapat mempengaruhi prestasi belajar yang akan diraih, antara lain adalah pendidikan orang tua dan sosial ekonomi orang tua yang meliputi pekerjaan dan pendapatan orang tua.

Berdasarkan beberapa penelitian terdahulu, terdapat beberapa faktor yang dapat mempengaruhi prestasi belajar diantaranya pendidikan. pekerjaan dan pendapatan orang tua. Ketiga faktor ini menjadi penting untuk diteliti kembali karena dalam penelitian terdahulu terbukti ketiga faktor ini signifikan berpengaruh terhadap prestasi belajar siswa. Dengan kondisi yang berbeda dengan penelitian terdahulu maka dilakukan penelitian di SMA Negeri 15 Surabaya untuk menjawab permasalahan tentang adakah pengaruh pendidikan, pekerjaan dan pendapatan orang tua terhadap prestasi belajar.

Faktor pendidikan orang tua, dalam Ensiklopedi Pendidikan dijelaskan bahwa pendidikan adalah suatu usaha sadar memfasilitasi orang sebagai pribadi yang utuh sehingga teraktualisasi dan terkembangkan potensinya mencapai taraf pertumbuhan dan perkembangan yang dikehendaki melalui belajar (Munandir, 2001). Sementara itu Purwanto (2004) berpendapat bahwa pendidikan adalah pimpinan yang diberikan dengan sengaja oleh orang dewasa kepada anak-anak, dalam pertumbuhannya (jasmani dan rohani) agar berguna bagi diri sendiri dan bagi masyarakat. Sedangkan Menurut UURI No. 20 Tahun 2003 tentang Sistem Pendidikan Nasional Bab I Ketentuan Umum Pasal 1 Pendidikan adalah usaha sadar dan terencana untuk mewujudkan suasana belajar dan proses pembelajaran agar peserta didik secara aktif mengembangkan potensi dirinya untuk memiliki 
kekuatan spiritual keagamaan, pengendalian diri, kepribadian, kecerdasan, akhlak mulia serta keterampilan yang diperlukan dirinya, masyarakat, bangsa dan negara.

Adapun jenjang pendidikan menurut Ihsan (2011) terdiri dari pendidikan dasar, pendidikan menengah, dan pendidikan tinggi. Sedangkan menurut pasal 14 UURI No 20 Tahun 2003 tentang Sistem Pendidikan Nasional menyatakan bahwa Jenjang pendidikan formal terdiri atas pendidikan dasar, pendidikan menengah, dan pendidikan tinggi. (1) Pendidikan dasar merupakan jenjang pendidikan yang melandasi jenjang pendidikan menengah. Pendidikan dasar berbentuk sekolah dasar (SD) dan madrasah ibtidaiyah (MI) atau bentuk lain yang sederajat serta sekolah menengah pertama (SMP) dan madrasah tsanawiyah (MTs), atau bentuk lain yang sederajat; (2) Pendidikan Menegah terdiri atas pendidikan menengah umum dan pendidikan menengah kejuruan. Pendidikan menengah berbentuk sekolah menengah atas (SMA), madrasah aliyah (MA), sekolah menengah kejuruan (SMK), dan madrasah aliyah kejuruan (MAK), atau bentuk lain yang sederajat. (3) Pendidikan tinggi merupakan jenjang pendidikan setelah pendidikan menengah yang mencakup program pendidikan diploma, sarjana, magister, spesialis, dan doktor yang diselenggarakan oleh pendidikan tinggi. Perguruan Tinggi dapat berbentuk akademi, politeknik, sekolah tinggi, institut, atau universitas.

Sedangkan menurut Nurseno (2009) secara lebih terperinci dapat kita jumpai stratifikasi pendidikan sebagai berikut: (1) pendidikan sangat tinggi (profesfor, doktor); (2) pendidikan tinggi (sarjana, mahasiswa); (3) pendidikan menengah (SMA); (4) pendidikan rendah (SD dan SMP); (4) tidak berpendidikan (buta huruf).

Dalam penelitian ini yang dimaksud dengan tingkat pendidikan orang tua adalah tingkat pendidikan menurut jenjang pendidikan yang telah ditempuh, melalui pendidikan formal di sekolah berjenjang dari tingkat yang paling rendah sampai tingkat yang paling tinggi, yaitu dari pendidikan dasar (SD \& SMP sederajat), pendidikan menengah (SMA, SMK, MA, MAK sederajat), sarjana dan pasca sarjana. Orang tua yang memiliki pendidikan yang tinggi mempunyai dorongan yang besar untuk menyekolahkan anak mereka. Bagaimana gambaran siswa dari keluarga yang berpendidikan akan mempunyai kondisi belajar dan prestasi belajar yang berbeda dengan siswa dari keluarga yang tidak berpendidikan. Hal ini memberikan pengaruh dan dorongan positif maupun negatif yang akan mempengaruhi prestasi belajar anak.

Berikutnya faktor pekerjaan orang tua, Sejak tahun 1976 hingga saat ini, konsep dan defenisi perihal ketenagakerjaan yang dipakai Badan Pusat Statistik adalah sama. Konsep dan defenisi tersebut sesuai dengan The Labour Force Concept yang disarankan oleh International Labor Organization (ILO). Konsep dan definisi yang digunakan oleh Badan Pusat Statistik dalam penelitian ketenagakerjaan sejak tahun 1976 adalah sebagai berikut: (1) Bekerja adalah mereka yang melakukan suatu pekerjaan dengan maksud memperoleh atau membantu memperoleh pendapatan atau keuntungan dan lamanya bekerja paling sedikit 1 jam yang secara kontiniu dalam seminggu yang lalu (seminggu sebelum pencacahan). Dengan demikian pekerjaan keluarga tanpa upah yang membantu dalam satu usaha/kegiatan ekonomi, dimasukkan sebagai pekerja. (2) Mengurus Rumah Tangga adalah mereka yang mengurus rumah tangga tanpa mendapatkan upah, misalnya ibu-ibu rumah tangga atau anaknya yang membantu mengurus 
rumah tangga. Sebaliknya pembantu rumah tangga yang mendapatkan upah walaupun pekerjaannya mengurus rumah tangga dianggap bekerja. (3) Kegiatan lainnya kegiatan seseorang selain disebutkan di atas, yakni mereka yang sudah pensiun, penerima royalty, penerima deviden dan orang-orang yang cacat jasmani (buta, bisu dan sebagainya) yang tidak mampu melakukan pekerjaan. (4) Status pekerjaan adalah kedudukan seseorang dalam melakukan pekerjaan di suatu unit usaha/kegiatan, meliputi: (a) Berusaha sendiri adalah bekerja atau berusaha dengan menanggung resiko secara ekonomis, yaitu dengan tidak kembalinya ongkos produksi yang telah dikeluarkan dalam rangka usahanya tersebut, serta tidak menggunakan pekerja tak dibayar, termasuk yang sifat pekerjaannya memerlukan teknologi atau keahlian khusus. (b) Buruh/karyawan/pegawai adalah seseorang yang bekerja pada orang lain atau instansi/kantor/perusahaan secara tetap dengan menerima upah/gaji baik berupa uang maupun barang. Pekerjaan orang tua meliputi wiraswasta, swasta, PNS, pensiunan, dan ibu rumah tangga dianggap memenuhi standar untuk dapat memenuhi kebutuhan atau layak yang berpengaruh terhadap kegiatan belajar dan prestasi belajar siswa.

Selanjutnya faktor pendapatan orang tua diartikan setiap hasil jerih payah orang tua yang dapat dinilai dengan tingkat atau nilai tertentu. Berdasarkan jenisnya dibedakan pendapatan menjadi dua (BPS, 2004) yaitu: (a) pendapatan berupa barang, dan (b) pendapatan berupa uang. Sedangkan bidang kegiatannya, pendapatan meliputi pendapatan sektor formal dan pendapatan sektor informal. Pendapatan sektor formal adalah segala penghasilan baik berupa barang atau uang yang bersifat regular dan diterimakan biasanya balas jasa atau kontraprestasi di sektor formal yang terdiri dari pendapatan berupa uang, meliputi: gaji, upah dan hasil investasi dan pendapatan berupa barang-barang meliputi: beras, pengobatan, transportasi, perumahan, maupun yang berupa rekreasi. Pendapatan sektor informal adalah segala penghasilan baik berupa barang maupun uang yang diterima sebagai balas jasa atau kontraprestasi di sektor informal yang terdiri dari pendapatan dari hasil investasi, pendapatan yang diperoleh dari keuntungan sosial, dan pendapatan dari usaha sendiri, yaitu hasil bersih usaha yang dilakukan sendiri, komisi dan penjualan dari hasil kerajinan rumah.

Dalam penelitian ini yang dimaksud dengan pendapatan orang tua adalah penghasilan berupa uang yang diterima sebagai balas jasa dari kegiatan baik dari sektor formal dan informal selama satu bulan dalam satuan rupiah.Bagaimana pun aktivitas yang dilakukan seorang anak membutuhkan finansial dari orang tuanya. Contohnya: anak dalam belajar akan sangat memerlukan sarana penunjang belajarnya, yang kadang-kadang yang harganya mahal tidak dapat terjangkau oleh orang tua. Bila kebutuhannya tidak terpenuhi maka akan menjadi penghambat bagi anak dalam pembelajaran.

Temuan penelitian tentang prestasi belajar diantaranya: Siti Maesaroh (2009) menyebutkan Status sosial ekonomi orang tua dengan indikator pendidikan, pekerjaaan dan pendapatan orang tua berpengaruh positif dan signifikan terhadap prestasi belajar siswa". Sedangkan Hamid Darmadi (2006), diketahui terdapat hubungan positif yang signifikan antara tingkat pendidikan, pendapatan orang tua dengan prestasi belajar siswa di sekolah dan tidak terdapat hubungan antara jenis pekerjaan orang tua dengan prestasi belajar siswa di sekolah. Ana Purwati (2010) menyatakan bahwa secara langsung, status sosial ekonomi orang tua berpengaruh positif dan signifikan terhadap prestasi belajar ekonomi siswa, secara tidak 
langsung maupun pengaruh total, status sosial ekonomi orang tua berpengaruh positif dan signifikan terhadap perilaku konsumsi yang diintermediasi oleh prestasi belajar.

Saifi and Mehmood (2011)menyatakan bahwa "income, parent's education and occupation, material possessed at home, transport and servants as the indicators of SES and data were analyzed through percentages. The findings indicated that parent's education and occupation and facilities at home affect the student's achievement". Akinsanya Omolade O, et. al. (2011) pada "Relative Effects of Parents' Occupation, Qualification and Academic Motivation of Wards on Students' Achievement in Senior Secondary School Mathematics in Ogun State" menyimpulkan bahwa "parents' education has the highest significant influence on the academic achievement of students in Mathematics while the effect of academic motivation had the least effect among the variables which exerted significant effects on students' academic achievement in Mathematics".

Qaiser Suleman, et. al. (2011) menyatakan bahwa that parental socioeconomic status; parent's educational level, parental occupational level; and parental income level affect the academic achievement of students at secondary level. Zarina Akhtar (2012) menyatakan bahwa "Linear regression showed mother's education, income, has positive effect on achievement.The linear regression equation was used to get SES score of each student. The obtained SES score was interpreted by five SES classes/groups. Serta Lucy Stella Atieno Juma et al. (2012) menyatakan bahwa "The study established that the girl students' from high family income performed better than from those fromlow income families. Parents with high level of education greatly enhanced girl students' academicachievement. Moderate family sizes of about 4 children had a big positive influence on girl students'academic achievement. The study concluded that family income, parental level of education, birth orderand family size influenced academic achievement of girls in secondary schools".

Dengan demikian, tujuan penelitian ini diantaranya: (1) Menganalisis pengaruh pendidikan, pekerjaan dan pendapatan orang tua terhadap prestasi belajar ekonomi secara parsial; (2) Menganalisis pengaruh pendidikan, pekerjaan dan pendapatan orang tua terhadap prestasi belajar ekonomi secara simultan.

\section{METODE PENELITIAN}

Jenis penelitian yang digunakan adalah penelitian deskriptif karena penelitian ini bertujuan untuk mengetahui pengaruh pendidikan $\left(\mathrm{X}_{1}\right)$, pekerjaan $\left(\mathrm{X}_{2}\right)$ dan pendapatan orang tua $\left(\mathrm{X}_{3}\right)$ terhadap prestasi belajar ekonomi $(\mathrm{Y})$. Sedangkan pendekatan yang digunakan adalah pendekatan kuantitatif dimana penelitian ini didasarkan pada angka-angka dan perhitungan secara matematis untuk menguji kebenaran suatu permasalahan.

Berikut rancangan penelitian dalam model hubungan antar variabel penelitian ditunjukkan pada gambar di bawah ini: 


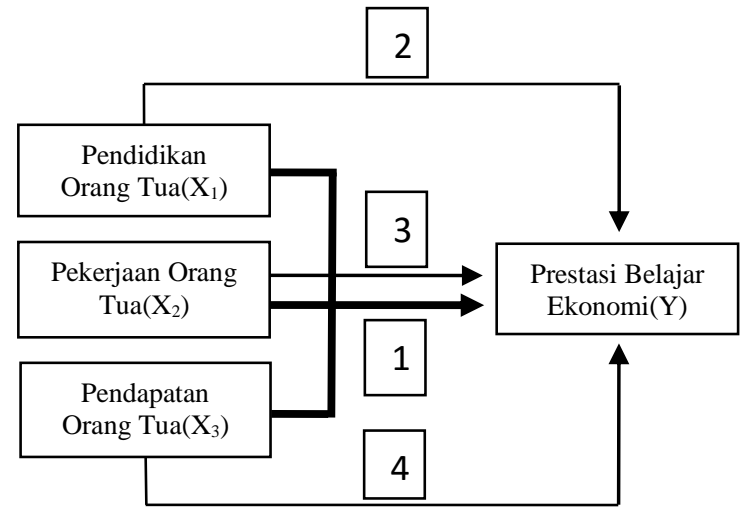

Gambar 1. Model Hubungan antar Variabel Penelitian

Populasi dalam penelitian ini adalah seluruh siswa SMA Negeri 15 Surabaya tahun pelajaran2012-2013. Populasi sasaran dalam penelitian ini adalah seluruh siswa kelasXI IPS dan XII IPS SMA Negeri 15 Surabaya yang berjumlah kurang lebih 91 siswa. Sedangkan cara pengambilan sampel yang representative adalah Proporsional random sampling dengan ukuran sampel yang digunakan sejumlah 74 siswa dari 91 siswa. Model pengukuran yang digunakan untuk menjaring data pada variabel-variabel penelitian ini dengan dokumentasi dan wawancara.

\section{HASIL PENELITIAN DAN PEMBAHASAN}

\section{Hasil Penelitian}

1. Prestasi Belajar

Nilai KKM prestasi belajar siswa kelas XI IPS dan XII IPS SMA negeri 15 Surabaya sebesar 77. Prestasi belajar siswa terendah sebesar 76 dan tertinggi sebesar 89. Hal ini menunjukkan bahwa kelas XI IPS terdapat sebanyak 5,56\% siswa yang memiliki prestasi belajar ekonomi dibawah KKM, $3,70 \%$ siswa memiliki prestasi belajar sama dengan KKM dan 90,74\% siswa memiliki prestasi belajar berada di atas KKM. Sedangkan kelas XII IPS tidak terdapat siswa yang memiliki prestasi belajar ekonomi dibawah KKM, terdapat $10 \%$ siswa memiliki prestasi belajar sama dengan KKM dan 90\% siswa memiliki prestasi belajar berada di atas KKM. Atau sebanyak 4,05\% siswa yang memiliki prestasi belajar ekonomi dibawah KKM, 5,41\% siswa memiliki prestasi belajar sama dengan KKM dan 90,54\% siswa memiliki prestasi belajar berada di atas KKM dari total siswa.

2. Pendidikan Orang Tua

Pendidikan ayah siswa diantaranya 50\% siswa memiliki seorang ayah dengan pendidikan Sarjana, sedangkan sisanya 33,78\% siswa memiliki seorang ayah dengan pendidikan SMA/sederajat; $12,16 \%$ siswa memiliki seorang ayah dengan pendidikan Pascasarjana; 2,70\% siswa memiliki seorang ayah dengan pendidikan Diploma dan $1,35 \%$ siswa memiliki seorang ayah dengan pendidikan SD. Adapun pendidikan ibu siswa meliputi 45,95\% siswa memiliki seorang ibu dengan pendidikan Sarjana, sedangkan sisanya $35,14 \%$ siswamemiliki seorang ibu dengan pendidikan SMA/sederajat; 9,46\% siswa memiliki seorang ibu dengan pendidikan diploma; 6,76\% siswa memiliki 
seorang ibu dengan pendidikan Pascasarjana, 1,35\% siswa memiliki seorang ibu dengan pendidikan SMP/sederajat dan 1,35\% memiliki seorang ibu dengan pendidikan SD.

3. Pekerjaan Orang Tua

Pekerjaan ayah siswa diantaranya $54,05 \%$ siswa memiliki seorang ayah sebagai pegawai swasta, sedangkan sisanya $21,62 \%$ siswa memiliki seorang ayah sebagai PNS; $18,92 \%$ siswa memiliki seorang ayah yang bekerja sebagai wiraswasta dan $5,41 \%$ siswa memiliki seorang ayah pensiunan. Sedangkan pekerjaan ibu siswa diantaranya 55,41\% siswa memiliki seorang ibu yang tidak bekerja, sedangkan sisanya 27,03\% siswa memiliki seorang ibu sebagai PNS; $9,46 \%$ siswa memiliki seorang ibu yang bekerja sebagai pegawai swasta dan $8,11 \%$ siswa memiliki seorang ibu yang bekerja sebagai wiraswasta.

4. Pendapatan Orang Tua

Pendapatan orang tua siswa diantaranya $1,35 \%$ siswa memiliki orang tua dengan pendapatan kurang dari Rp. 2 juta, 48,65\% siswa memiliki orang tua dengan pendapatan sebanyak Rp. 2,1 - 5 juta, sedangkan sisanya 28,38\% siswamemiliki orang tua dengan pendapatan sebanyak Rp. 5,1 - 8 juta; $13,51 \%$ siswa memiliki orang tua dengan pendapatan sebanyak Rp. 8,1 - 11 juta,dan $8,11 \%$ siswa memiliki orang tua dengan pendapatan lebih dari Rp. 11 juta.

Berdasarkan hasil penelitian dalam analisis regresi linear berganda, maka bentuk persamaan regresi sebagai berikut:

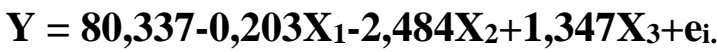

Hasil persamaan analisis regresi linear berganda diatas dapat di interpretasikan dengan penjelasan berikut:

1. Nilai konstanta (a) sebesar 80,337 menyatakan jika tidak terjadi perubahan nilai variabel Pendidikan Orang Tua $\left(X_{1}\right)$, Pekerjaan Orang Tua $\left(X_{2}\right)$ dan Pendapatan Orang Tua $\left(\mathrm{X}_{3}\right)$, maka Prestasi Belajar Ekonomi (Y) yang akan diperoleh adalah sebesar 80,337\%.

2. Koefisien regresi Pendidikan Orang Tua $\left(X_{1}\right)$ sebesar -0,203artinya setiap perubahan variabel Pendidikan Orang Tua $\left(\mathrm{X}_{1}\right)$ akan berpengaruh negatif pada Prestasi Belajar Ekonomi (Y) sebesar 0,203 dengan asumsi variabel Pekerjaan Orang Tua $\left(\mathrm{X}_{2}\right)$ dan Pendapatan Orang Tua $\left(\mathrm{X}_{3}\right)$ tetap. Nilai koefisien regresi negatif menunjukkan pengaruh yang ditimbulkan tidak searah, dimana naiknya variabel Pendidikan Orang Tua $\left(\mathrm{X}_{1}\right)$ sebesar $1 \%$ berpengaruh pada penurunan Prestasi Belajar Ekonomi (Y) sebesar 0,203\% dan turunnya variabel Pendidikan Orang Tua $\left(\mathrm{X}_{1}\right)$ sebesar $1 \%$ berpengaruh pada kenaikan Prestasi Belajar Ekonomi (Y) sebesar 0,203\%.

3. Koefisien regresi Pekerjaan Orang Tua $\left(\mathrm{X}_{2}\right)$ sebesar $-2,484$ artinya setiap perubahan variabel Pekerjaan Orang Tua $\left(\mathrm{X}_{2}\right)$ akan berpengaruh negatif pada Prestasi Belajar Ekonomi (Y) sebesar 2,484 dengan asumsi variabel Pendidikan Orang Tua $\left(\mathrm{X}_{1}\right)$ dan Pendapatan Orang Tua $\left(\mathrm{X}_{3}\right)$ tetap. Nilai koefisien regresi negatif menunjukkan pengaruh yang ditimbulkan tidak searah, dimana naiknya variabel Pekerjaan Orang Tua $\left(\mathrm{X}_{2}\right)$ sebesar $1 \%$ berpengaruh pada penurunan Prestasi Belajar Ekonomi (Y) sebesar 2,484\% dan turunnya variabel Pekerjaan Orang Tua $\left(\mathrm{X}_{2}\right)$ sebesar $1 \%$ berpengaruh pada kenaikan Prestasi Belajar Ekonomi (Y) sebesar 2,484\%. 
4. Koefisien regresi Pendapatan Orang Tua $\left(X_{3}\right)$ sebesar 1,347 artinya setiap perubahan variabel Pendapatan Orang Tua $\left(\mathrm{X}_{3}\right)$ akan berpengaruh pada Prestasi Belajar Ekonomi (Y) sebesar 1,347 dengan asumsi variabel Pendidikan Orang Tua $\left(\mathrm{X}_{1}\right)$ dan Pekerjaan Orang Tua $\left(\mathrm{X}_{2}\right)$ tetap. Nilai koefisien regresi positif menunjukkan pengaruh yang ditimbulkan searah, dimana naiknya variabel Pendapatan Orang Tua $\left(\mathrm{X}_{3}\right)$ sebesar $1 \%$ berpengaruh pada kenaikan Prestasi Belajar Ekonomi (Y) sebesar 1,347\% dan turunnya variabel Pendapatan Orang Tua $\left(\mathrm{X}_{3}\right)$ sebesar $1 \%$ berpengaruh pada penurunan Prestasi Belajar Ekonomi (Y) sebesar 1,347\%.

Lebih lanjut uji simultan diperoleh nilai F-hitung sebesar 5,454 dengan tingkat signifikan kurang dari $5 \%$ yaitu 0,002 , sehingga $\mathrm{Ha}$ diterima dan $\mathrm{Ho}$ ditolak. Hal ini berarti semua atau ketiga variabel bebas yaitu pendidikan, pekerjaan dan pendapatan orang tua yang dimasukkan ke dalam model secara bersama-sama mempunyai pengaruh yang signifikan terhadap variabel prestasi belajar ekonomi. Dengan demikian, ada pengaruh secara bersama-sama antara pendidikan, pekerjaan, dan pendapatan orang tua terhadap prestasi belajar ekonomi pada siswa SMA Negeri 15 Surabaya diterima.Sedangkan besarnya pengaruh variabel bebas yang terdiri dari pendidikan, pekerjaan, dan pendapatan orang tua secara bersama-sama terhadap variabel terikat yaitu prestasi belajar ekonomi dapat dilihat dari nilai adjusted R-square yang dihasilkan sebesar 0,155. Hal ini menunjukkan bahwa prestasi belajar ekonomi dipengaruhi oleh pendidikan, pekerjaan dan pendapatan orang tua hanya sebesar $15,5 \%$ sedangkan $84,5 \%$ dipengaruhi oleh faktor-faktor lain selain variabel penelitian ini.

Adapun uji parsial menunjukkan tidak semua variabel pengaruhnya signifikan. Uji parsial menunjukkan variabel pendidikan orang tua memiliki t hitung sebesar -0,441 dengan signifikansi 0,660; variabel pekerjaan orang tua memiliki t hitung sebesar -3,141 dengan signifikansi 0,02; variabel pendidikan orang tua memiliki $t$ hitung sebesar 3,382 dengan signifikansi 0,01.

Berdasarkan data diatas bahwa variabel pendidikan orang tua secara statistik mempunyai nilai signifikan $>0,05$, yang berarti variabel pendidikan orang tua secara parsial tidak terdapat pengaruh signifikan terhadap prestasi belajar ekonomi,variabel pekerjaan orang tua dan pendapatan orang tua mempunyai nilai signifikan $<0,05$, yang berarti variabel pekerjaan orang tua dan pendapatan orang tua secara parsial terdapat pengaruh signifikan terhadap prestasi belajar ekonomi.

\section{Pembahasan}

1. Pengaruh Pendidikan, Pekerjaan dan Pendapatan Orang Tua Secara Bersamasama Terhadap Prestasi Belajar Ekonomi

Berdasarkan hasil analisis dengan pengujian menggunakan SPSS menunjukkan pengaruh signifikan dan terdapat hubungan positif antara pendidikan, pekerjaan dan pendapatan orang tua secara bersama-sama terhadap prestasi belajar ekonomi. Hal ini memberikan pengertian bahwa semakin positif baik pendidikan, pekerjaan maupun pendapatan orang tua secara bersama-sama maka semakin tinggi pula prestasi belajar ekonomi siswa. Sebaliknya semakin negatif pendidikan, pekerjaan maupun pendapatan orang tua secara bersama-sama maka semakin rendah pula prestasi belajar ekonomi. Pernyataan tersebut sesuai dengan penelitian sebelumnya yang dilakukan oleh Siti Maesaroh (2009), dan Hayatun Nufus 
(2009), hasil penelitian menunjukkan status sosial ekonomi orang tua dengan indikator pendidikan, pekerjaaan dan pendapatan orang tua berpengaruh signifikan terhadap prestasi belajar siswa. Selain itu Qaiser Suleman, et. al. (2011), hasil penelitian menunjukkan that parental socio-economic status; parent's educational level, parental occupational level, and parental income level affect the academic achievement of students.

Berdasarkan analisa data didapatkan hasil koefisien diterminasi (Koefisien Adjusted R-square) menunjukkan bahwa hubungan pendidikan, pekerjaan dan pendapatan orang tua terhadap prestasi belajar ekonomi. Koefisien Adjusted $R$-square sebesar 15,5\% dapat diartikan bahwa besarnya hubungan pendidikan, pekerjaan dan pendapatan orang tua secara bersamasama terhadap prestasi belajar ekonomi sebesar $15,5 \%$ sisanya $84,5 \%$ dijelaskan variabel lain yang tidak masuk dalam penelitian ini. Sedangkan hasil uji F pada tabel 4.11 yaitu nilai F-hitung sebesar 5,454 dengan tingkat signifikan kurang dari $5 \%$ yaitu 0,002 . Hal ini berarti semua variabel bebas yang dimasukkan ke dalam model secara bersama-sama mempunyai pengaruh yang signifikan terhadap variabel prestasi belajar ekonomi. Oleh karena itu terdapat pengaruh signifikan pendidikan, pekerjaan, dan pendapatan orang tua secara bersama-sama terhadap prestasi belajar ekonomi pada siswa SMA Negeri 15 Surabaya dapat diterima.

2. Pengaruh Pendidikan Orang Tua Terhadap Prestasi Belajar Ekonomi

Berdasarkan hasil analisis menunjukkan tidak terdapat pengaruh yang signifikan dan terdapat hubungan negatif antara pendidikan orang tua dengan prestasi belajar ekonomi pada siswa SMA Negeri 15 Surabaya. Hal ini memberikan pengertian bahwa semakin negatif atau rendah pendidikan orang tua akan diiringi dengan meningkatkan prestasi belajar ekonomi. Demikian pula sebaliknya, semakin positif atau tinggi pendidikan orang tua akan diiringi dengan menurunnya prestasi belajar ekonomi.

Keadaan tersebut berbanding terbalik dengan teori yang disampaikan oleh Suryabrata (2004) menyatakan bahwa faktor diluar diri siswa yang mempengaruhi prestasi belajar yang akan diraih antara lain adalah pendidikan orang tua. Begitu juga menurut Dalyono (2009) menyatakan bahwa faktor yang mempengaruhi prestasi belajar berasal dari tinggi rendahnya pendidikan orang tua, Dan dipertegas lagi oleh Yulisanti (2000) bahwa semakin tinggi tingkat pendidikan maka semakin tinggi prestasi akademik dan produktivitas yang dicapai.

Hal ini juga tidak sesuai dengan hasil penelitian terdahulu yang dilakukan oleh Siti Maesaroh (2009), Hayatun Nufus (2009), Hakkinen et. al. (2003), Fortheringham et. al. (2001), Lockheed et. al. (1989), Wade (1962), Shea (2002), Hanushek (2005) dan Niles (1981) yang menyimpulkan bahwa secara parsial tingkat pendidikan orang tua berpengaruh signifikan terhadap prestasi belajar siswa.

Sehingga dapat dikatakan pendidikan orang tua tidak bisa menjamin meningkatkan prestasi belajar siswa, karena tidak sesuai atau kebalikan dengan teori dan penelitian sebelumnya yang menyebutkan semakin tinggi pendidikan orang tua maka semakin tinggi prestasi belajar siswa yang akan dicapai. Tidak adanya pengaruh signifikan dalam penelitian ini dapat disebabkan oleh berbagai faktor, baik orang tua maupun siswa. 
Seyogyanya kesadaran orang tua akan pentingnya pendidikan dipengaruhi oleh latar belakang pendidikan orang tua itu sendiri. Sebab secara psikologis, orang tua yang pendidikannya tinggi, biasanya akan berusaha sekuat tenaga agar kelak anaknya minimal sama pendidikannya dengan orang tuanya dan sangat berpengaruh terhadap keberhasilan anak dalam belajar, baik di rumah maupun di sekolah. Hal ini sesuai dengan yang sampaikan oleh Indrakusuma (2003) menyatakan bahwa bagaimanapun juga anak dari keluarga yang berpendidikan akan mempunyai gambaran dan aspirasi-aspirasi yang berbeda dengan anak dari keluarga biasa saja. Situasi dari keluarga berpendidikan akan memberikan dorongan yang positif terhadap anak agar berpacu untuk meraih cita-cita yang tinggi melalui prestasi belajar yang tinggi pula.

Apalagi dari data menyebutkan sebagian besar siswa bertempat tinggal bersama orang tua sebesar $98,65 \%$, hanya $1,35 \%$ yang tinggal bersama saudara dan sebagian besar keberadaan orang tua siswa yaitu $100 \%$ ayah masih hidup, 98,65\% ibu masih hidup dan 1,35\% ibu meninggal dunia. Artinya bahwa semestinya orang tua bisa lebih banyak untuk memberikan dorongan yang positif terhadap anak agar berpacu untuk meraih prestasi belajar ekonomi. Sebab mata pelajaran ekonomi merupakan mata pelajaran yang menentukan untuk bisa masuk perguruan tinggi negeri (PTN) jalur undangan dalam rangka meraih cita-cita yang lebih tinggi.

Sebaliknya disisi lain prestasi belajar ekonomi yang dicapai oleh siswa dipengaruhi oleh faktor yang berada dalam diri individu yang sedang belajar terutama kemampuan yang dimilikinya. Faktor kemampuan dalam diri siswa berpengaruh terhadap prestasi belajar ekonomi yang dicapai dari pada yang berasal dari luar diri siswa dalam hal ini adalah pendidikan orang tua. Hal ini sesuai dengan yang disampaikan Suryabrata (2004) dan Dalyono (2004) menyatakan prestasi belajar yang diperoleh seseorang dipengaruhi oleh faktor internal yang berasal dari dalam diri siswa yaitu intelegensi dan bakat.

Selanjutnya, pengutamaan intelegensi serta bakat siswa juga sejalan dengan kebijakan Pemerintah Kota Surabaya melalui Dinas Pendidikan Kota Surabaya selaku pelaksana penerimaan siswa baru tentang penerimaan siswa baru lebih mengedepankan kemampuan akademis calon siswa. Hal ini dibuktikan dengan penerimaan siswa baru masuk SMA Negeri 15 Surabaya sebagai sekolah RSBI, calon siswa harus memenuhi syarat kualifikasi untuk mengikuti test. Adapun syarat kualifikasi yang dimaksud adalah nilai UN minimal berjumlah 34 atau rata-rata 8,5 dan tidak ada nilai mata pelajaran UN dibawah 7,5. Nilai UN tersebut dijumlah dengan hasil test potensi akademik (TPA) yang dilaksanakan secara independen, sehingga siswa yang diterima merupakan siswa yang mempunyai kemampuan akademis yang baik atau pilihan.

Atas dasar kemampuan intelengensi dan bakat siswa dapat meraih prestasi belajar ekonomi yang dicapai sehingga faktor pendidikan orang tua tidak berdampak pengaruhnya. Dengan demikian terdapat pengaruh signifikan pendidikan orang tua terhadap prestasi belajar ekonomi pada siswa SMA Negeri 15 Surabaya tidak dapat diterima dan tidak terbukti kebenarannya. 
3. Pengaruh Pekerjaan Orang Tua Terhadap Prestasi Belajar Ekonomi

Berdasarkan hasil pengujian menunjukkan terdapat pengaruh yang signifikan dan terdapat hubungan negatif antara pekerjaan orang tua dengan prestasi belajar ekonomi pada siswa SMA Negeri 15 Surabaya. Hal ini memberikan pengertian bahwa semakin negatif pekerjaan orang tua akan diiringi dengan meningkatkan prestasi belajar ekonomi. Demikian pula sebaliknya, semakin positif pekerjaan orang tua akan diiringi dengan menurunnya prestasi belajar ekonomi.

Hasil pengujian dalam penelitian ini mendukung teori yang disampaikan oleh Suryabrata (2004), Slameto (2003) dan Dimyati (1990) menyatakan bahwa faktor diluar diri siswa yang mempengaruhi prestasi belajar yang akan diraih antara lain adalah sosial ekonomi keluarga dalam hal ini adalah jenis pekerjaan orang tua.

Keadaan ini juga sesuai dengan hasil penelitian terdahulu yang dilakukan olehSiti Maesaroh (2009), Hayatun Nufus (2009), Muhammad Choirul Yusuf (2002), dan Lockheed et. al. (1989) menyimpulkan bahwa jenis pekerjaan orang tua berpengaruh signifikan terhadap prestasi belajar. Juga telah disampaikan dalam penelitian lain oleh Qaiser Suleman, et. al. (2011) menyimpulkan bahwa theparental occupational level affect the academic achievement of students at secondary level dan Saifi and Mehmood (2011) menyimpulkan bahwa the findings indicated that parent's occupation affect the student's achievement.

Sedangkan Wade (1962), menyimpulkan bahwa pekerjaan orang tua mempengaruhi tingkat kemampuan anak tetapi jika kedua orang tua bekerja berpengaruh secara negatif pada terhadap kemampuan anak. Jadi semakin banyak orang tua yang bekerja semakin mendorong anak untuk berprestasi tetapi dibalik itu semakin sibuk orang tua semakin negatif pengaruhnya terhadap prestasi anak. Hal ini dapat dilihat dari data sebesar $44,59 \%$ ayah dan ibu siswa bekerja dan 55,41\% ayah atau ibu siswa tidak bekerja menunjukkan bahwa ayah atau ibu yang bekerja mempunyai nilai prestasi belajar ekonomi lebih baik dari pada ayah dan ibu yang bekerja. Ayah dan ibu yang bekerja akan disibukkan dengan pekerjaannya sehingga tidak punya banyak waktu untuk memperhatikan belajar anak. Sebaliknya ayah atau ibu yang bekerja akan punya banyak waktu untuk memperhatikan belajar anak yang berdampak pada prestasi belajar anak.

Temuan lain menyebutkan 74 responden terdapat 41 atau 55,41\% pekerjaan ibu sebagai ibu rumah tangga atau tidak bekerja dan 33 atau 44,59\% ibu bekerja. Orang tua (ibu) yang tidak bekerja mempunyai banyak waktu luang untuk memberikan dorongan atau motivasi, perhatian dan mengontrol perkembangan anak dalam belajarnya baik di rumah maupun di sekolah sehingga anak menjadi terbantu untuk meraih prestasi belajarnya. Sementara orang tua (ibu) yang bekerja mempunyai waktu yang relatif sedikit untuk memberikan dorongan atau motivasi, perhatian dan mengontrol perkembangan anak dalam belajarnya baik di rumah maupun di sekolah sehingga menjadi berat bagi anak untuk memperoleh prestasi belajar yang diharapkan. Dengan demikian terdapat pengaruh signifikan pekerjaan orang tua terhadap prestasi belajar ekonomi pada siswa SMA Negeri 15 Surabaya dapat diterima dan terbukti kebenarannya. 
4. Pengaruh Pendapatan Orang Tua Terhadap Prestasi Belajar Ekonomi

Berdasarkan hasil analisis dengan pengujian menggunakan SPSS menunjukkan pengaruh signifikan dan terdapat hubungan positif antara pendapatan orang tua dengan prestasi belajar ekonomi pada siswa SMA Negeri 15 Surabaya. Hal ini dapat dilihat dari t-hitung pendapatan orang tua yang dihasilkan sebesar 3,382 dengan tingkat signifikan 0,001 kurang dari 0,05 atau $5 \%(\mathrm{sig}=0,000)$. Hasil analisis tersebut memberikan pengertian bahwa semakin positif pendapatan orang tua, akan diiringi dengan meningkatnya prestasi belajar ekonomi. Demikian pula sebaliknya, semakin negatif pendapatan orang tua, akan diiringi dengan menurunnya prestasi belajar. Sehingga pendapatan orang tua yang lebih besar akan dapat lebih meningkatkan prestasi belajar dalam diri siswa tersebut.

Hasil pengujian mendukung teori yang disampaikan Dalyono (2009), Suryabata (2004), Slameto (2003), dan Dimyati (1990). Begitu juga sesuai dengan penelitian terdahulu yang dilakukan oleh Shea (2002), Hanushek (2005), Niles (1981), Siti Maesaroh (2009), Hamid Darmadi (2006), dan Mafthukhah (2007) yang menyimpulkan bahwa pendapatan orang tua berpengaruh positif dan signifikan terhadap prestasi belajar. Demikian juga menurut Qaiser Suleman, et. al. (2011), hasil penelitian menunjukkan parental income level affect the academic achievement of students, dan menurut Zarina Akhtar (2012), hasil penelitian menunjukkan family income influenced academic achievement.

Menurut Dalyono (2009) mengemukakan salah satu faktor yang berpengaruh terhadap prestasi belajar adalah besar kecilnya penghasilan. Sementara Dimyati (1990) mengemukakan salah satu faktor yang paling berpengaruh terhadap prestasi belajar ialah status sosial ekonomi orang tua, siswa yang status ekonomi atau pendapatan orang tuanya baik, berkecukupan, mampu, kaya menunjukkan nilai yang lebih tinggi dalam tes kemampuan akademik, dalam tes hasil belajar.

Hubungan positif antara pendapatan orang tua dan prestasi belajar ekonomi siswa menjelaskan seberapa kuat pendapatan orang tua yang dimiliki individu siswa akan banyak menentukan terhadap kebutuhan belajar, baik dalam pemberian biaya pendidikan, pemberian kebutuhan fasilitas belajar maupun tambahan belajar atau les privat di luar jam pelajaran sekolah. Apabila orang tua siswa mempunyai pendapatan yang tinggi maka akan terus berusaha untuk memenuhi kebutuhan belajar tersebut sehingga apa yang diinginkan memperoleh prestasi belajar dapat tercapai sesuai dengan keinginannya. Hal ini dapat dilihat dari t-hitung pendapatan orang tua yang dihasilkan positif sebesar 3,382, memberikan pengertian bahwa semakin tinggi pendapatan orang tua, akan diiringi dengan meningkatnya prestasi belajar ekonomi dan sebaliknya.

Pendapatan orang tua adalah salah satu indikator faktor sosial ekonomi keluarga yang penting karena hal tersebut merupakan salah satu pendorong semangat berprestasi. Pendapatan orang tua dapat memberi semangat dan lebih fokus dalam belajar terhadap siswa dalam mengikuti kegiatan pembelajaran yang dilaksanakan karena memperoleh nafkah kehidupannya yang memadai dan kurang dari tekanan-tekanan fundamental. 
Pendapatan orang tua yang tinggi dapat mencurahkan perhatian lebih mendalam kepada pendidikan anaknya untuk meraih prestasi belajar dan ia tidak disulitkan dengan perkara kebutuhan-kebutuhan dalam kehidupannya justru akan lebih mudah memenuhi segala kebutuhan sekolah dan keperluan lain. Hal tersebut sesuai dengan yang telah disampaikan oleh Hamalik (2001) yang mengatakan bahwa keadaan sosial ekonomi yang baik dapat mendorong dalam belajar. Masalah biaya pendidikan juga merupakan sumber kekuatan dalam belajar karena kurangnya biaya pendidikan akan sangat mengganggu kelancaran belajar.

Dengan demikian, orang tua dapat melakukan berbagai upaya melalui pendapatannya yang besar untuk peningkatan prestasi belajar ekonomi siswa. Hal ini berarti bahwa selain siswa itu sendiri memiliki tanggung jawab dan orientasi sukses dalam mencapai tujuan yang diharapkan untuk meningkatkan prestasi belajar ekonomi mereka tetapi juga orang tua bertanggung jawab untuk membiayai dan memfasilitasi kebutuhan-kebutuhan pendukung belajar. Sehingga ada pengaruh signifikan pendapatan orang tua terhadap prestasi belajar ekonomi pada siswa SMA Negeri 15 Surabaya dapat diterima dan terbukti kebenarannya.

\section{KESIMPULAN}

1. Ada pengaruh signifikan dan positif pendidikan, pekerjaan dan pendapatan orang tua terhadap prestasi belajar ekonomi siswa SMA Negeri 15 Surabaya. Hal ini menunjukkan seluruh variabel bebas secara bersama-sama memberikan kontribusi atau mendukung terhadap prestasi belajar ekonomi siswa.

2. Tidak ada pengaruh signifikan pendidikan orang tua terhadap prestasi belajar siswa SMA Negeri 15 Surabaya, berarti pendidikan orang tua yang tinggi tidak diikuti prestasi belajar ekonomi yang meningkat. Hal ini ditunjukkan bahwa pendidikan orang tua tidak menjamin atau mendukung prestasi belajar ekonomi siswa.

3. Ada pengaruh signifikan dan negatif pekerjaan orang tua terhadap prestasi belajar ekonomi siswa SMA Negeri 15 Surabaya, berarti pekerjaan orang tua berpengaruh terhadap tinggi rendahnya prestasi belajar ekonomi yang dicapai siswa tetapi tidak searah. Hal ini menunjukkan bahwa ayah dan ibu bekerja tidak diikuti prestasi belajar ekonomi yang meningkat. Sebaliknya ayah atau ibu bekerja diikuti prestasi belajar yang meningkat.

4. Ada pengaruh signifikan dan positif pendapatan orang tua terhadap prestasi belajar ekonomi siswa SMA Negeri 15 Surabaya, berarti semakin tinggi pendapatan orang tua akan diikuti peningkatan prestasi belajar. Hal ini dapatmenunjukkan bahwa pendapatan orang tua mendukung prestasi belajar ekonomi siswa. 


\section{DAFTAR RUJUKAN}

Akhtar, Zarina. 2012. Socio-economic Status Factors Effecting the Students Achievement: A Predictive Study. International Journal of Social Sciences and Education ISSN: 2223-4934 Volume: 2 Issue: 1 January 2012

Akinsanya, Omolade O. et al.2011. Relative Effects of Parents' Occupation, Qualification and Academic Motivation of Wards on Students' Achievement in Senior Secondary School Mathematics in Ogun State. British Journal of Arts and Social Sciences ISSN: 2046-9578, Vol.3 No.2

Azwar, Saifuddin. 2010. Tes Prestasi Fungsi dan Pengembangan Pengukuran Prestasi Belajar. Yogyakarta: Pustaka Pelajar.

Dalyono. 2009. Psikologi Pendidikan. Jakarta: Rineka Cipta

Darmadi, Hamid. 2006. Korelasi antara Status Sosial Ekonomi Orang Tua Dengan Kualitas Pembelajarn Siswa Di Sekolah. Jurnal Pendidikan dan Pengajaran STKIP PGRI Pontianak No. 1/XXV/2006.

Furchan, A. 2004.Pengantar Penelitian dalam Pendidikan, Yogyakarta: PustakaPelajar.

Gunarsah, Singgih D. 2000. Psikologi Untuk Keluarga. Jakarta: PT BPK Gunung Mulia

Gintings, Abdorrakhman. 2010. Esensi Praktis Belajar dan Pembelajaran. Bandung: Humaniora

Hadikusumo, Kunaryo. 1999. Pengantar Pendidikan. Semarang: IKIP Semarang PRESS

Hamalik, Oemar. 2001. Proses Belajar dan Mengajar. Jakarta: PT Bumi Aksara

Haryono, Agung, 2008. Pengaruh Sistem Pembelajaran dan Status Sosial Ekonomi Terhadap Tingkat Ekonomic Literacy Siswa SMA di Kota Malang. Disertasi. Malang: Universitas Negeri Malang.

Ihsan, Fuad, 2011. Dasar-dasar Kependidikan. Jakarta: Rineka Cipta.

Indrakusuma, A, 1993.Pengantar Ilmu Pendidikan. Surabaya: Usaha Nasional

Indriyanto, Bambang, Sumber Daya Pendidikan: Reaktulisasi Pasal 1( Ayat 10) Undang-Undang Nomor 2 Tahun 1989 Tentang Sistem Pendidikan Nasional.

Lucy Stella Atieno Juma et al. 2012. Impact of Family Socio-Economic Status on Girl Students' Academic Achievement in Secondary Schools in Kenya: A Case Study of Kisumu East District. Educational Research (ISSN:21415161) Vol 3(3) pp. 297-310, March 2012.

Mahmud, M, Dimyati. 1990. PsikologiPendidikan. Yogyakarta: BPFE.

Maesaroh, Siti. 2009. Pengaruh Status Sosial Ekonomi Orang Tua, Lingkungan Sekolah Dan Motivasi Belajar Terhadap Prestasi Belajar Mata Pelajaran. Malang: Universitas Islam Negeri Maulana Malik Ibrahim Malang.

Munandir, 2001.Ensiklopedi Pendidikan. Malang: UM Press.

Nazir, Moh. 1998. Metode Penelitian. Jakarta: Ghalia Indonesia.

Nurseno, 2009. Theory and Application of Sociology. Solo: PT. Tiga Serangkai Pustaka Mandiri.

NurWahidin, Pantja. 2006. Pengaruh Faktor Internal dan Faktor External Terhadap Prestasi Belajar Matematika Siswa Kelas 1 SMA Di Makassar.Tesis. Surabaya: UniversitasNegeri Surabaya. 
Purwanto, M. Ngalim. 2004. Ilmu Pendidikan Teori dan Praktek. Bandung: PT. Remaja Rosdakarya.

Purwati, Ana. 2010. Pengaruh Status Sosial Ekonomi Orang Tua Dan Persepsi Siswa Atas Lingkungannya Terhadap Perilaku Konsumsi Yang Diintermediasi Prestasi Belajar Ekonomi Siswa SMA sekota Malang. Jurnal Ekonomi Bisnis, th. 16, no. 1, Maret 2011.

Qaiser, Suleman, et. al. 2011. Effects of Parental Socioeconomic Status on the Academic Achievement of Secondary School Students in District Karak (Pakistan). International Journal of Social Sciences Tomorrow (ISNN, 2277-6168), Vol. 1 No. 78, September 2012.

Riduwan. 2011. Belajar Mudah Penelitian. Bandung: CV. Alfabeta

Saifi, S. \& Mehmood, T. 2011. Effects of socio-economic status on students achievement. International Journal of Social Sciences and Education, 119128

Schunk, Dale H. Pintrich, Paul R. and Meece, Judith L, 2012.Motivasi Dalam Pendidikan (Teori, Penelitian, dan Aplikasi). Jakarta: PT. Indeks.

Soejoto, Ady. 2007. Dukungan Dunia Industri Dan Kondisi Sosial Ekonomi Masyarakat Terhadap Mutu Lulusan Satuan Pendidikan. Disertasi. Malang: FE Universitas Brawijaya Malang.

Soekanto, Soerjono. 2002. Sosiologi Suatu Pengantar. Jakarta: Rajawali Press.

Sugiyono, 2010.Metode Penelitian Kuantitatif Kualitatif dan $R \& D$. Bandung: CV. Alfabeta.

Sunyoto, Danang. 2012. Analisis Validitas \& Asumsi Klasik. Yogyakarta: Gava Media.

Suryabrata, Sumadi. 2004. Psikologi Pendidikan. Jakarta: PT Raja Grafindo Persada.

Taniredja, Tukiran dan Mustafidah, Hidayati. 2011. Penelitian Kuantitatif. Bandung: CV. Alfabeta.

Undang-Undang No 20 Tahun 2003 Tentang Sistem Pendidikan Nasional. Jakarta: Depdiknas.

Undang-Undang Nomor 13 Tahun 2003 tentang Tenaga Kerja. Jakarta: Depnaker. Wahyono, Teguh. 2012. Analisis Statistik Mudah dengan SPSS 20. Jakarta: PT. Elex Media Komputindo.

Wiyono, Bambang Budi. Burhanuddin. 2008. Metodologi Penelitian. Departemen Pendidikan Nasional Universitas Negeri Malang 